\title{
Ideas and perspectives: Is dark carbon fixation relevant for oceanic primary production estimates?
}

\author{
Federico Baltar ${ }^{1, *}$ and Gerhard J. Herndl ${ }^{1,2}$ \\ ${ }^{1}$ Department of Limnology and Bio-Oceanography, University of Vienna, Althanstraße 14, 1090 Vienna, Austria \\ ${ }^{2}$ NIOZ, Department of Marine Microbiology and Biogeochemistry, Royal Netherlands Institute for Sea Research, \\ Utrecht University, P.O. Box 59, 1790 AB Den Burg, the Netherlands \\ * Invited contribution by Federico Baltar, recipient of the EGU Biogeosciences Division Outstanding \\ Young Scientists Award 2016.
}

Correspondence: Federico Baltar (federico.baltar@univie.ac.at) and Gerhard J. Herndl (gerhard.herndl@univie.ac.at)

Received: 31 May 2019 - Discussion started: 11 June 2019

Revised: 3 September 2019 - Accepted: 9 September 2019 - Published: 2 October 2019

\begin{abstract}
About half of the global primary production (PP) is generated in the euphotic layer of the ocean. The ${ }^{14} \mathrm{C}$ method developed by Steemann Nielsen (Nielsen, 1952) more than half a century ago has been the most frequently used method to determine PP in all aquatic systems. This method includes dark incubations to exclude the nonphototrophic dissolved inorganic carbon (DIC) fixation. The presence of significant dark DIC fixation rates has been habitually used to suggest the inaccuracy of the ${ }^{14} \mathrm{C}$ method to determine autotrophic phytoplankton primary production. However, we suggest that the dark DIC fixation rates should be incorporated into global oceanic carbon production estimates since the total production of organic matter does not originate only from photosynthesis but also from other processes such as chemoautotrophic and anaplerotic processes. Here we analyzed data collected over almost 30 years from the longest available oceanic time series and calculated that the inclusion of dark DIC fixation would increase oceanic PP estimates by $5 \%-22 \%$ when total dark DIC fixation is included or by $2.5 \%-11 \%$ when only considering the nighttime DIC fixation. We conclude that dark DIC fixation should be included into global oceanic primary production estimates as it represents newly synthesized organic carbon (ca. 1.2-

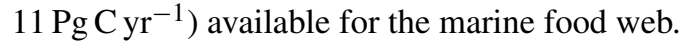

\section{Introduction}

Primary production (PP) is arguably one of the most important metabolic processes, and half of the global PP is generated in the euphotic layer of the ocean (Field et al., 1998). Thus, it is crucial to accurately estimate marine PP rates to understand better the marine $\mathrm{C}$ cycle. The ${ }^{14} \mathrm{C}$ method to estimate aquatic primary production is based on incubating environmental water samples with a known concentration of ${ }^{14} \mathrm{C}$-bicarbonate, measuring the concentration of ${ }^{14} \mathrm{C}$ incorporated into microbial biomass, i.e., measuring the conversion rate of inorganic to organic carbon. One of the key issues associated with the interpretation of the results derived from this method is the need to assume that dissolved inorganic carbon (DIC) uptake is associated essentially only with photosynthetic activity of phytoplankton (Harris et al., 1989; Ignatiades et al., 1987; Legendre et al., 1983; Petersen, 1979; Prakash et al., 1991; Taguchi, 1983). This implies that dark DIC fixation by other organisms such as heterotrophs or chemoautotrophs is considered insignificant, because if substantial DIC fixation occurred in the dark, then this method would not be a reliable measure of photosynthetic primary production (Prakash et al., 1991). Although Steemann Nielsen originally thought that dark DIC fixation rates would only amount to about $1 \%$ of DIC fixation in the presence of solar radiation, he promptly realized that dark DIC fixation could be up to $>50 \%$ of that under solar radiation (Nielsen, 1960; Prakash et al., 1991). Despite these findings, the standard protocol of the ${ }^{14} \mathrm{C}$ method, analyses and 
interpretation of the data has remained essentially unchanged for decades.

However, over the past 2-3 decades our understanding of the metabolic potential of marine microbes has expanded dramatically. It is now accepted that, besides autotrophic phytoplankton, there are many chemoautotrophs and heteroand mixotrophs inhabiting the oxygenated upper ocean with the ability to mediate dark DIC fixation. A great metabolic potential related to DIC fixation was uncovered with the development and application of (meta)genomic tools to marine microbial communities (Moran, 2008). High dark DIC fixation rates attributed to chemoautotrophic and heterotrophic prokaryotes have been reported at the surface (Alonso-Sáez et al., 2010; Li and Dickie, 1991; Li et al., 1993; Markager, 1998; Prakash et al., 1991) and in the deep ocean (Baltar et al., 2010, 2016; Herndl et al., 2005; Reinthaler et al., 2010). In particular, the rates of DIC fixation parallel those of prokaryotic heterotrophic production in the deep pelagic ocean (Reinthaler et al., 2010; Baltar et al., 2016). The contribution of the organic carbon supplied by dark DIC fixation to the prokaryotic carbon demand in the deep ocean is comparatively similar to the supply of sinking particulate organic carbon flux (Baltar et al., 2010; Reinthaler et al., 2010). DIC fixation due to chemoautotrophy is assumed to be relatively more important in aphotic than photic waters due to the reported light sensitivity of ammonia oxidation, which is a chemoautotrophic process (Horrigan and Springer, 1990; Merbt et al., 2012). However, substantial chemoautotrophy such as nitrification was found to take place not only in the mesopelagic but also in epipelagic waters, where it plays a significant role in providing $\mathrm{N}$ for new oceanic production (Yool et al., 2007). Yet, while the dark DIC fixation via nitrification is not directly fed by solar energy, it indirectly relies on the availability of a substrate (ammonia / ammonium) that itself is a breakdown product of organic molecules that were originally fashioned using solar energy. In general, chemoautotrophy is widespread in the marine environment amounting to an estimated global oceanic DIC fixation of $0.77 \mathrm{Pg} \mathrm{C} \mathrm{yr}^{-1}$ (Middelburg, 2011). This estimated DIC fixation rate is similar to the amount of organic $\mathrm{C}$ supplied by the worlds' rivers and buried in oceanic sediments (Middelburg, 2011).

DIC fixation is not only performed by photoautotrophs, but chemoautotrophs and heterotrophs incorporate $\mathrm{CO}_{2}$ via a wide range of carboxylation reactions (anaplerotic reactions and the synthesis of fatty acids, nucleotides and amino acids) that form part of their central and peripheral metabolic pathways (Dijkhuizen and Harder, 1984; Erb, 2011). Since many ecologically relevant compounds are metabolized via these "assimilatory carboxylases", it has been recently suggested that these enzymes can be relevant for the global C cycle along with "autotrophic carboxylases" (Erb, 2011). In the ocean in particular, DIC incorporation via anaplerotic reactions (i.e., chemical reactions that form intermediates of a metabolic pathway) plays an important role in compensating metabolic imbalances in marine bacteria under olig- otrophic conditions, contributing up to $>30 \%$ of the carbon incorporated into biomass (González et al., 2008; Palovaara et al., 2014). Moreover, it has also been shown that if the heterotrophic metabolism of bacteria is suddenly intensified (e.g., after an input of organic matter), dark DIC fixation rates and the expression of transcripts associated with key anaplerotic enzymes increase proportionally (Baltar et al., 2016). Considering the oligotrophic nature of most of the ocean and the sporadic, pulsed input of organic matter it is possible that anaplerotic reactions may at times contribute a larger proportion to dark (and total) DIC fixation. However, despite evidence of dark DIC fixation taking place, it remains unknown how much anaplerotic reactions contribute to oceanic DIC fixation.

Bearing all these discoveries on oceanic DIC fixation in mind, it is not surprising that the dark DIC fixation rates have been an issue for the interpretation of the ${ }^{14} \mathrm{C}$ method to measure phytoplankton PP. Traditionally, the way to deal with the dark fixation in the ${ }^{14} \mathrm{C}$ method is to perform light and dark incubations and then subtract the rates obtained under dark conditions from that in the light incubations. The presence of significant dark DIC fixation rates has been habitually attributed to the inaccuracy of the ${ }^{14} \mathrm{C}$ method to determine phytoplankton PP.

However, we believe that it might be sensible to go a step further and suggest that the dark DIC fixation rates measured with the ${ }^{14} \mathrm{C}$ method should be incorporated into global carbon production estimates. In the oceanic environment, the total production of organic matter does not originate only from photosynthesis but also from chemoautotrophic and anaplerotic processes. These other DIC fixation pathways also produce organic $\mathrm{C}$ not only in the daytime but also during nighttime. Thus, although it makes sense to exclude the dark DIC fixation rates if the aim is to estimate photoautotrophic production only, dark DIC fixation (at least the one occurring during the nighttime) should actually be added to the photoautotrophic production if we want to arrive at a realistic estimate on total organic carbon production via DIC fixation.

\section{Contribution of dark inorganic carbon fixation to overall oceanic photoautotrophic carbon dioxide fixation}

Here, we used the publicly available data on the ${ }^{14} \mathrm{C}$ PP method from the longest oceanic time series stations (ALOHA: $22^{\circ} 45^{\prime} \mathrm{N} 158^{\circ} 00^{\prime} \mathrm{W}$; BATS: $31^{\circ} 40^{\prime} \mathrm{N} 64^{\circ} 10^{\prime} \mathrm{W}$ ) to determine the relative importance of dark DIC fixation relative to light-based DIC fixation in the epipelagic ocean. Herein, PP refers to the traditional way of estimating PP in the ocean (i.e., the $\mathrm{C}$ fixed during light minus that fixed in dark incubation). We defined "total DIC fixation" as the sum of light plus dark DIC fixation. First we compared the temporal and vertical changes in the ratio between dark and light 
DIC fixation. Then, we integrated the rates and used the stoichiometry of nitrification to calculate the overall relative contribution of dark DIC fixation and nitrification-based DIC fixation to the dark and total organic carbon production. With this, we aim at providing an estimate of the amount of $\mathrm{C}$ being missed with the traditionally light-based PP estimates and make a case for the inclusion of the dark DIC fixation in oceanic organic carbon production estimates.

The available data (i.e., light and dark DIC fixation rates) were obtained from the databases of BATS for 1989-2017 and of ALOHA for 1989-2000 (Fig. 1). The maximum sampling depth was deeper for ALOHA (175 m) than for BATS $(150 \mathrm{~m})$. Yet, both the ALOHA and BATS stations showed a pronounced increase with depth in the dark to light DIC fixation ratio spanning from 0 to 2.8 (Fig. 1). This ratio of dark to light DIC fixation was generally lower at ALOHA than at BATS, particularly in the top $100 \mathrm{~m}$ layer. A clearer and stronger seasonality was found for BATS than for ALOHA, provoked by differences in stratification during the summer and vertical mixing during the winter due to their differences in latitude (Figs. 1 and 2). Interestingly, in the BATS dataset, there was a tendency towards a detectable higher ratio of dark to light DIC fixation in the top half of the euphotic layer (0$65 \mathrm{~m}$ ) from the year 2012 to 2017 than in the preceding years. It is not clear what the reason might be for this increase in the dark to light DIC fixation ratio in recent years. It might be associated, however, to changes in the vertical structure of the water column over this time span as indicated in the shifts observed in temperature, salinity and density $\left(\sigma_{t}\right)$ during the same period (Fig. 2). The $\sigma_{t}$ isopycnal of 26 reached and remained deeper than $200 \mathrm{~m}$ during the years 2012-2017 (Fig. 2c). This has caused a deepening of the mixed layer, causing a decrease in chlorophyll $a$ concentrations in shallow waters and a deepening of the deep chlorophyll maximum (Fig. 2d). Thus, this relative decrease in chlorophyll $a$ (and PP) relative to the dark DIC fixation might explain the increase in the dark to light DIC fixation ratio in recent years while also suggesting that autotrophic DIC fixation seems more sensitive to a deepening of the mixed layer than dark DIC fixation.

We then compiled and integrated the data for all available depths (down to 150 and $175 \mathrm{~m}$ at BATS and ALOHA, respectively) to calculate how much the inclusion of dark DIC fixation would increase the total PP estimates in the epipelagic waters (Table 1). Due to the strong vertical differences observed in the ratio of dark to light DIC fixation (Fig. 1), we also decided to subdivide the integration of the epipelagic water column into a shallow and a deep layer. The deep chlorophyll maximum (DCM) was located, most of the time (except during spring blooms), in the deeper layer (Fig. 2d). At ALOHA, the inclusion of dark fixation would increase PP by $3.7 \%$ in the shallow layer $(0-65 \mathrm{~m})$ and by $8.6 \%$ in the deep layer $(65-175 \mathrm{~m})$. When integrating for the whole depth range of the euphotic layer at ALOHA, the inclusion of dark fixation increases PP estimates by $5.1 \%$.
At BATS, this contribution is much higher with $17.3 \%$ and $36.5 \%$ for the shallow $(0-70 \mathrm{~m})$ and deep $(70-150 \mathrm{~m})$ layer. When integrated for the whole water column, the dark DIC fixation increases PP estimated at BATS by $22.1 \%$. The reasons for these differences found between BATS and ALOHA are unknown but could be related to the contrasting nature of primary production found in these regions. In BATS, a negligible contribution from $\mathrm{N}_{2}$ fixation to $\mathrm{N}$ budget has been found from $\delta^{15} \mathrm{~N}$ budget exercises (Altabet, 1988) and inverse models (Wang et al., 2019). In contrast, in ALOHA, $\delta^{15} \mathrm{~N}$ budgets and inversion models estimate that $30 \%$ to $50 \%$ of export production is sustained by $\mathrm{N}_{2}$ fixation (Karl et al., 1997; Wang et al., 2019).

To estimate the potential relative contribution of chemoautotrophy and anaplerotic reactions to dark DIC fixation, we calculated the potential proportion of nitrification to dark DIC fixation based on the global euphotic nitrification rate of $0.195 \mathrm{~d}^{-1}$ obtained by Yool et al. (2007) (Table 1). For that we used published $\mathrm{NH}_{4}^{+}$concentrations from ALOHA (Segura-Noguera et al., 2014) and from BATS (Lipschultz, 2001). The calculated depth-integrated ammonium oxidation by this method $\left(1.5 \mathrm{mmol} \mathrm{m} \mathrm{m}^{-2} \mathrm{~d}^{-1}\right)$ is remarkably similar to the rate $\left(1.6 \mathrm{mmol} \mathrm{m} \mathrm{m}^{-2} \mathrm{~d}^{-1}\right)$ obtained by Dore and Karl (1996) for ALOHA using inhibitor-sensitive dark ${ }^{14} \mathrm{C}$ uptake assays. We then used the stoichiometry of ammonia oxidation (i.e., ratio of $\mathrm{CO}_{2}$ fixed per $\mathrm{NH}_{4}^{+}$oxidized of 0.1 ) to calculate the potential contribution of ammonia oxidation (nitrification) to the dark DIC fixation (Belser, 1984; Bayer et al., 2019). The remaining dark fixation was assumed to originate from other chemoautotrophic processes and anaplerotic metabolism. We found that the integrated contribution of nitrification to dark DIC fixation is relatively low at both stations $(8.8 \%$ and $2 \%$ at ALOHA and BATS, respectively), suggesting that most of the dark fixation $(91.2 \%$ and $98 \%$ at ALOHA and BATS, respectively) is performed by chemoautotrophs other than ammonia oxidizers and/or anaplerotic metabolism. This could include aerobic anoxygenic photosynthetic bacteria (AAnPB) and oxidizers of nitrite, carbon monoxide, sulfur, etc. (Hügler and Sievert, 2011).

Since C fixation occurs both at daytime (photosynthesis, chemosynthesis, anaplerotism) and during the night (chemosynthesis, anaplerotism), a more appropriate measure of the total PP would include the DIC fixation over the entire day (and not only during daytime). The DIC fixation measured during light incubation experiments represents the fixation performed by all organisms (photoautotrophs, chemoautotrophs and anaplerotic metabolic processes), hence including dark fixation during the daytime. The DIC fixation in the dark bottle accounts for the DIC fixation by all organisms during the nighttime. Assuming that the dark DIC fixation is constant over the diel cycle, we can calculate the nighttime DIC fixation by dividing the dark daily DIC fixation (in $\mathrm{mg} \mathrm{C} \mathrm{m} \mathrm{d}^{1}$ ) by half (assuming a $12 \mathrm{~h}$ dark period). That would imply that the inclusion of dark DIC fixation in PP estimates would increase total PP (DIC fixation) by 

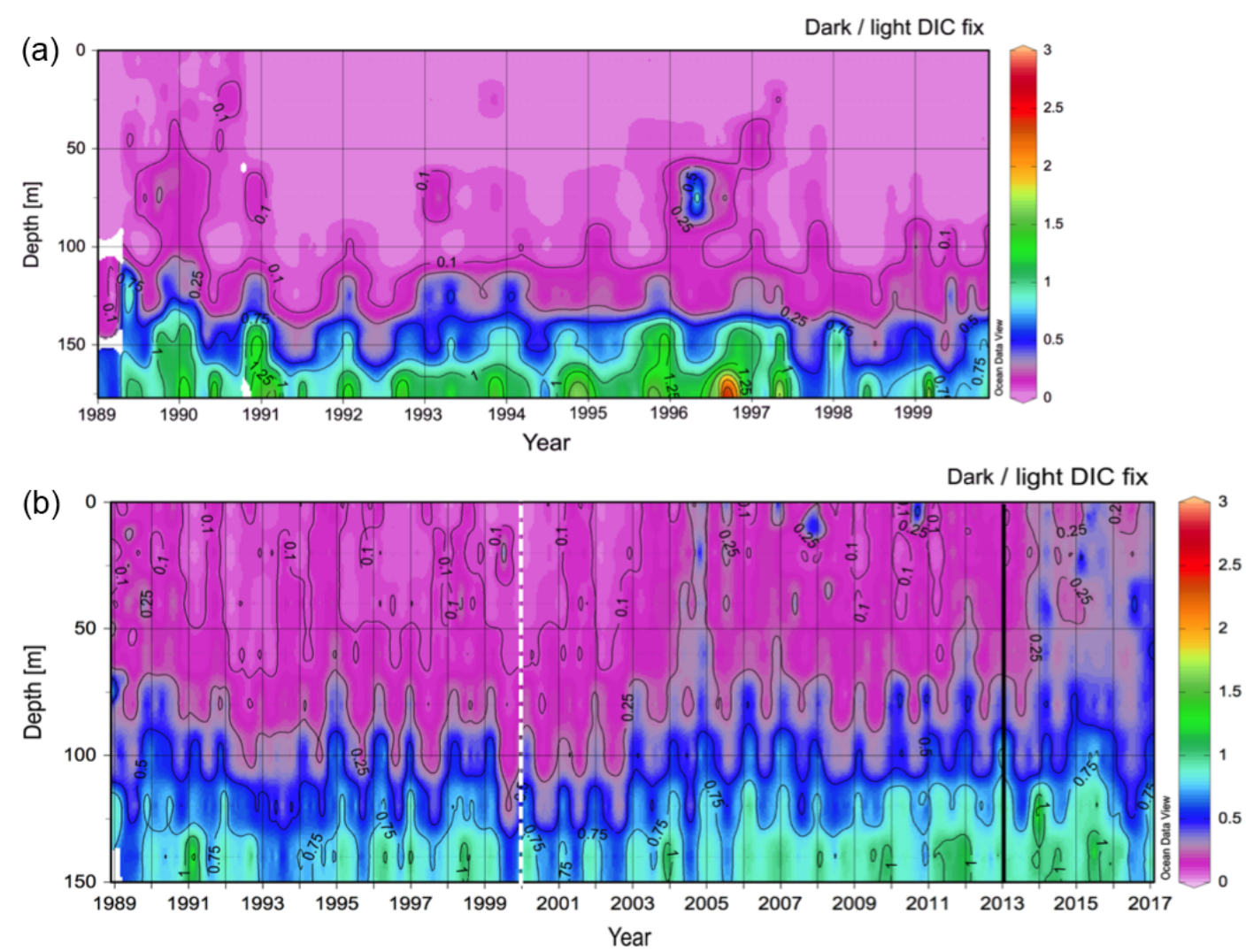

Figure 1. Variation in the ratio of dark to light DIC fixation rates (a) at ALOHA (from 1989 to 2000) and (b) at BATS (from 1989 to 2017). The dashed line in the plots for BATS indicates the recent years on record in the ALOHA dataset. The solid black line highlights a potential shift in the year 2013.

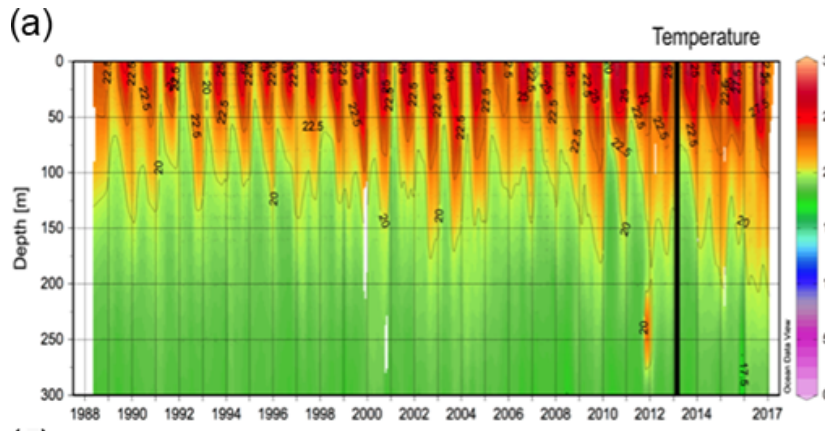

(c)

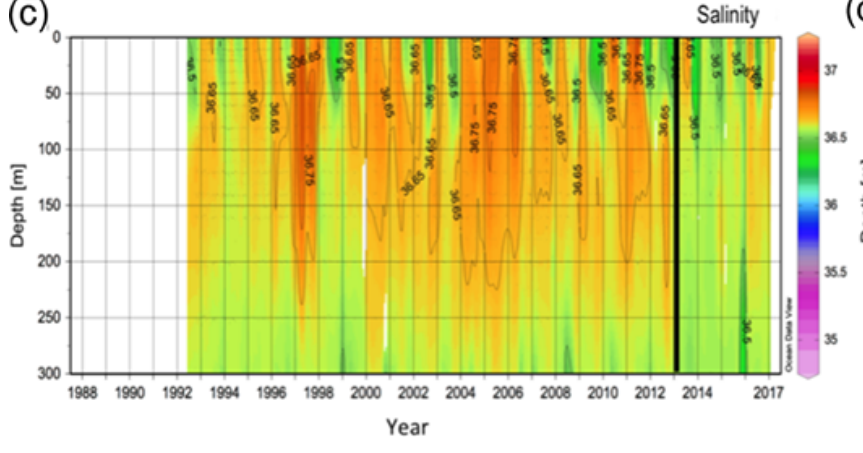

(b) Density $(\sigma t)$

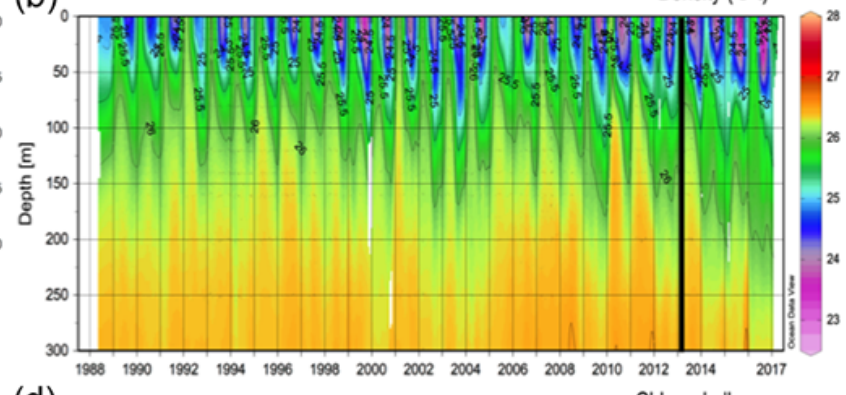

(d)

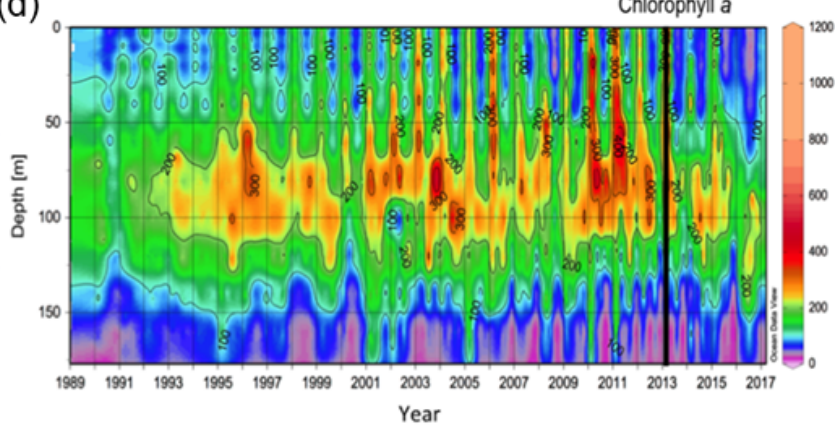

Figure 2. Variation in (a) temperature $\left({ }^{\circ} \mathrm{C}\right)$, (b) salinity, (c) density $(\sigma t)$ and (d) chlorophyll $a\left(\mathrm{ng} \mathrm{kg}^{-1}\right)$ at BATS (from 1989 to 2017). The solid black line highlights a potential shift in the year 2013. 
Table 1. Integrated total primary production (PP) (i.e., light-dark DIC fixation), dark DIC fixation and percentage of dark to total PP at station ALOHA (0-175 m) from 1989 to 2000 (11 years) and at station BATS (0-150 m) from 1989 to 2017 (29 years). The contribution of nitrification to dark fixation was calculated based on the global euphotic nitrification rate of $0.195 \mathrm{~d}^{-1}$ (Yool et al., 2007) using published $\mathrm{NH}_{4}^{+}$concentrations from ALOHA $\left(7.98 \mathrm{mmol} \mathrm{m}^{2}\right.$ ) (Segura-Noguera et al., 2014) and from BATS (7.84 mmol m²) (Lipschultz, 2001). The stoichiometry of ammonia oxidation (ratio of $\mathrm{CO}_{2}$ fixed per $\mathrm{NH}_{4}^{+}$oxidized of 0.1 ) was used to calculate the potential contribution of ammonia oxidation (nitrification) to the dark $\mathrm{CO}_{2}$ fixation. The remaining dark fixation was assumed to be from other chemoautotrophic and anaplerotic processes.

\begin{tabular}{|c|c|c|c|c|}
\hline ALOHA & & & & \\
\hline $\begin{array}{l}\text { Depth } \\
\text { range }(\mathrm{m})\end{array}$ & $\begin{array}{r}\text { Total PP } \\
\left(\mathrm{mg} \mathrm{C}^{-2} \mathrm{~d}^{-1}\right)\end{array}$ & $\begin{array}{l}\text { Dark DIC fixation } \\
\left(\mathrm{mg} \mathrm{C} \mathrm{m}^{-2} \mathrm{~d}^{-1}\right)\end{array}$ & $\begin{array}{l}\% \text { of dark } \\
\text { to total PP }\end{array}$ & $\begin{array}{r}\% \text { of dark to total PP } \\
\text { (calculated for daily } \\
12 \text { h dark fix) }\end{array}$ \\
\hline $0-65$ & 289.1 & 10.7 & 3.7 & 1.8 \\
\hline $65-175$ & 117.5 & 10.1 & 8.6 & 4.3 \\
\hline $0-175$ & 406.6 & 20.8 & 5.1 & 2.5 \\
\hline $\begin{array}{l}\text { Depth } \\
\text { range }(\mathrm{m})\end{array}$ & $\begin{array}{r}\text { Nitrification } \\
\left(\mathrm{mmol} \mathrm{NH}_{4}^{+} \mathrm{m}^{-2} \mathrm{~d}^{-1}\right)\end{array}$ & $\begin{array}{r}\% \text { dark DIC } \\
\text { fixation from } \\
\text { nitrification }\end{array}$ & $\begin{array}{r}\% \text { dark DIC fixation } \\
\text { from other } \\
\text { chemoautotrophic and } \\
\text { anaplerotic reactions }\end{array}$ & \\
\hline $0-70$ & 0.5 & 5.4 & 94.6 & \\
\hline $70-150$ & 1.1 & 12.5 & 87.5 & \\
\hline $0-150$ & 1.5 & 8.8 & 91.2 & \\
\hline \multicolumn{5}{|l|}{ BATS } \\
\hline $\begin{array}{l}\text { Depth } \\
\text { range }(\mathrm{m})\end{array}$ & $\begin{array}{r}\text { Total PP } \\
\left(\mathrm{mg} \mathrm{C}^{-2} \mathrm{~d}^{-1}\right)\end{array}$ & $\begin{array}{l}\text { Dark DIC fixation } \\
\left(\mathrm{mg} \mathrm{C} \mathrm{m}^{-2} \mathrm{~d}^{-1}\right)\end{array}$ & $\begin{array}{l}\% \text { of dark } \\
\text { to total PP }\end{array}$ & $\begin{array}{r}\% \text { of dark to total PP } \\
\text { (calculated for daily } \\
12 \mathrm{~h} \text { dark fix) }\end{array}$ \\
\hline $0-70$ & 314.2 & 54.3 & 17.3 & 8.6 \\
\hline $70-150$ & 103.8 & 37.9 & 36.5 & 18.2 \\
\hline $0-150$ & 418.0 & 92.2 & 22.1 & 11 \\
\hline $\begin{array}{l}\text { Depth } \\
\text { range }(\mathrm{m})\end{array}$ & $\begin{array}{r}\text { Nitrification } \\
\left(\mathrm{mmol} \mathrm{NH}_{4}^{+} \mathrm{m}^{-2} \mathrm{~d}^{-1}\right)\end{array}$ & $\begin{array}{r}\% \text { of dark DIC } \\
\text { fixation from } \\
\text { nitrification }\end{array}$ & $\begin{array}{r}\% \text { of dark DIC fixation } \\
\text { from other } \\
\text { chemoautotrophic and } \\
\text { anaplerotic processes }\end{array}$ & \\
\hline $0-70$ & 0.7 & 1.5 & 98.5 & \\
\hline $70-150$ & 0.9 & 2.7 & 97.3 & \\
\hline $0-150$ & 1.6 & 2.0 & 98.0 & \\
\hline
\end{tabular}

$2.5 \%$ at ALOHA and $11 \%$ at BATS (Table 1). It is important to realize that for anaplerotic DIC fixation this would be a conservative estimate since it has been observed that proteorhodopsin-harboring heterotrophic marine bacteria increase their DIC fixation due to anaplerotic reactions in response to light (González et al., 2008; Palovaara et al., 2014). Moreover, chemoautotrophic DIC fixation rates such as nitrification are reduced in the presence of light (Horrigan and Springer, 1990). Thus, the chemoautotrophic fixation taking place in the light bottles also represents a conservative estimate.

\section{Conclusions and implications}

Collectively, these results suggest that including total dark DIC fixation into actual PP estimates increases the total PP rates by $5 \%$ and $22 \%$ at ALOHA and BATS, respectively, and by $2.5 \%$ to $11 \%$ when only the nighttime DIC fixation is considered. Considering a net primary production rate (photoautotrophic) in the global ocean (Field et al., 1998) of ca. $50 \mathrm{Pg} \mathrm{Cyr}^{-1}$, this range of contribution of the dark DIC fixation (2.5\% to $22 \%$ of total PP) would translate into ca. 1.2 to $11 \mathrm{Pg} \mathrm{Cyr}^{-1}$. To put these numbers into context, the C flux associated with dark ocean $(>200 \mathrm{~m}$ ) chemoautotrophy is $0.11 \mathrm{Pg} \mathrm{Cyr}^{-1}$, and the total respiration C fluxes in the global ocean sediments, the dark ocean and in the euphotic 
zone are 1.2, 7.3 and $44 \mathrm{Pg} \mathrm{Cyr}^{-1}$, respectively (Dunne et al., 2007; Middelburg, 2011). This is a substantial amount of organic C produced via DIC fixation currently not accounted for in global $\mathrm{C}$ budget estimates, which might have implications for the $\mathrm{C}$ cycling by the heterotrophic food web. For instance, this, thus far, largely ignored and thus unaccounted source of newly synthesized organic $\mathrm{C}$ might help resolve the contrasting views of whether the ocean is net heterotrophic or net autotrophic (Duarte et al., 2013; Ducklow and Doney, 2013; Williams et al., 2013). It may also reconcile the imbalance between the deep ocean heterotrophic $\mathrm{C}$ demand and the sinking particulate organic C flux (Baltar et al., 2009; Burd et al., 2010; Steinberg et al., 2008). Moreover, the relevance of incorporating this dark DIC fixation in the estimates of total PP might become even more crucial if the tendency continues towards an increasing ratio of dark to total PP we observed over the past 5-year period for BATS. Overall, we suggest that the DIC fixation measured with the ${ }^{14} \mathrm{C}$ method under dark conditions (particularly during nighttime) should be seen as an integral part of the global ocean PP generating new particulate organic carbon potentially available for the marine food web.

Data availability. All data are available and were downloaded from the BATS (Bermuda Atlantic Time-series Study, http://bats.bios. edu, last access: 14 February 2019) and ALOHA (A Long-term Oligotrophic Habitat Assessment, http://hahana.soest.hawaii.edu/ hot, last access: 14 February 2019) station websites.

Author contributions. Federico Baltar and Gerhard J. Herndl contributed equally to the development of the paper.

Competing interests. The authors declare that they have no conflict of interest.

Acknowledgements. We would like to acknowledge the great effort of BATS (Bermuda Atlantic Time-series Study) and ALOHA (A Long-term Oligotrophic Habitat Assessment) stations for generating and making their data publically available. The constructive criticism of the three reviewers is gratefully acknowledged. Federico Baltar would also like to thank the European Geosciences Union for the EGU Biogeosciences Division Outstanding Young Scientists Award 2016. Thanks are also owed to colleagues for their nomination, collaboration and support with regards to this award.

Financial support. This study was funded by the Austrian Science Fund (FWF) project ARTEMIS (grant no. P28781-B21) to Gerhard J. Herndl, as well as the Rutherford Discovery Fellowship to Federico Baltar (by the Royal Society of New Zealand).
Review statement. This paper was edited by Jack Middelburg and reviewed by Andrew K. Sweetman and two anonymous referees.

\section{References}

ALOHA: Time series biogeochemical data, available at: http:// hahana.soest.hawaii.edu/hot, last access: 14 February 2019.

Alonso-Sáez, L., Galand, P. E., Casamayor, E. O., Pedrós-Alió, C., and Bertilsson, S.: High bicarbonate assimilation in the dark by Arctic bacteria, ISME J., 4, 1581-1590, 2010.

Altabet, M.: Variations in nitrogen isotopic composition between sinking and suspended particles: Implications for nitrogen cycling and particle transformation in the open ocean, Deep-Sea Res. Pt. A, 35, 535-554, 1988.

Baltar, F., Arístegui, J., Gasol, J. M., Sintes, E., and Herndl, G. J.: Evidence of prokaryotic metabolism on suspended particulate organic matter in the dark waters of the subtropical North Atlantic, Limnol. Oceanogr., 54, 182-193, 2009.

Baltar, F., Arístegui, J., Sintes, E., Gasol, J. M., Reinthaler, T., and Herndl, G. J.: Significance of non-sinking particulate organic carbon and dark $\mathrm{CO}_{2}$ fixation to heterotrophic carbon demand in the mesopelagic northeast Atlantic, Geophys. Res. Lett., 37, L09602, https://doi.org/10.1029/2010GL043105, 2010.

Baltar, F., Lundin, D., Palovaara, J., Lekunberri, I., Reinthaler, T., Herndl, G. J., and Pinhassi, J.: Prokaryotic responses to ammonium and organic carbon reveal alternative $\mathrm{CO}_{2}$ fixation pathways and importance of alkaline phosphatase in the mesopelagic North Atlantic, Front. Microbiol., 7, 1670, https://doi.org/10.3389/fmicb.2016.01670, 2016.

BATS station: Time series biogeochemical data, available at: http: //bats.bios.edu, last access: 14 February 2019.

Bayer, B., Vojvoda, J., Reinthaler, T., Reyes, C., Pinto, M., and Herndl, G. J.: Nitrosopumilus adriaticus sp. nov. and Nitrosopumilus piranensis sp. nov., two ammonia-oxidizing archaea from the Adriatic Sea and members of the class Nitrososphaeria, Int. J. Syst. Evol. Micr., 69, 1892-1902, 2019.

Belser, L.: Bicarbonate uptake by nitrifiers: effects of growth rate, $\mathrm{pH}$, substrate concentration, and metabolic inhibitors, Appl. Environ. Microbiol., 48, 1100-1104, 1984.

Burd, A. B., Hansell, D. A., Steinberg, D. K., Anderson, T. R., Arístegui, J., Baltar, F., Beaupre, S. R., Buesseler, K. O., DeHairs, F., Jackson, G. A., Kadko, D. C., Koppelmann, R., Lampitt, R. S., Nagata, T., Reinthaler, T., Robinson, C., Robison, B. H., Tamburini, C., and Tanaka, T.: Assessing the apparent imbalance between geochemical and biochemical indicators of meso-and bathypelagic biological activity: What the@ \$?! is wrong with present calculations of carbon budgets?, Deep-Sea Res. Pt. II, 57, 1557-1571, 2010.

Dijkhuizen, L. and Harder, W.: Current views on the regulation of autotrophic carbon dioxide fixation via the Calvin cycle in bacteria, Antonie Van Leeuwenhoek, 50, 473-487, https://doi.org/10.1007/bf02386221, 1984.

Dore, J. E. and Karl, D. M.: Nitrification in the euphotic zone as a source for nitrite, nitrate and nitrous oxide at Station ALOHA, Limnol. Oceanogr., 41, 1619-1628, 1996.

Duarte, C. M., Regaudie-de-Gioux, A., Arrieta, J. M., DelgadoHuertas, A., and Agustí, S.: The oligotrophic ocean is heterotrophic, Ann. Rev. Mar. Sci., 5, 551-569, 2013. 
Ducklow, H. W. and Doney, S. C.: What is the metabolic state of the oligotrophic ocean? A debate, Ann. Rev. Mar. Sci.e, 5, 525-533, 2013.

Dunne, J. P., Sarmiento, J. L., and Gnanadesikan, A.: A synthesis of global particle export from the surface ocean and cycling through the ocean interior and on the seafloor, Global Biogeochem. Cy., 21, GB4006, https://doi.org/10.1029/2006GB002907, 2007.

Erb, T. J.: Carboxylases in natural and synthetic microbial pathways, Appl. Environ. Microbiol., 77, 8466-8477, 2011.

Field, C. B., Behrenfeld, M. J., Randerson, J. T., and Falkowski, P.: Primary production of the biosphere: integrating terrestrial and oceanic components, Science, 281, 237-240, 1998.

González, J. M., Fernández-Gómez, B., Fernández-Guerra, A., Gómez-Consarnau, L., Sánchez, O., Coll-Lladó, M., del Campo, J., Escudero, L., Rodríguez-Martínez, R., Alonso-Sáez, L., Latasa, M., Paulsen, I., Nedashkovskaya, O., Lekumberri, I., Pinhassi, J., and Pedrós-Alió, C.: Genome analysis of the proteorhodopsin-containing marine bacterium Polaribacter sp. MED152 (Flavobacteria), P. Natl. Acad. Sci. USA, 105, 87248729, 2008.

Harris, G. P., Griffiths, F. B., and Thomas, D. P.: Light and dark uptake and loss of $14 \mathrm{C}$ : methodological problems with productivity measurements in oceanic waters, Hydrobiologia, 173, 95$105,1989$.

Herndl, G. J., Reinthaler, T., Teira, E., Aken, H. v., Veth, C., Pernthaler, A., and Pernthaler, J.: Contribution of Archaea to total prokaryotic production in the deep Atlantic Ocean, Appl. Environ. Microbiol., 71, 2303-2309, 2005.

Horrigan, S. G. and Springer, A. L.: Oceanic and estuarine ammonium oxidation: effects of light, Limnol. Oceanogr., 35, 479-482, 1990.

Hügler, M. and Sievert, S. M.: Beyond the Calvin cycle: autotrophic carbon fixation in the ocean, Ann. Rev. Mar. Sci., 3, 261-289, 2011.

Ignatiades, L., Karydis, M., and Pagou, K.: Patterns of dark ${ }^{14} \mathrm{CO}_{2}$ incorporation by natural marine phytoplankton communities, Microb. Ecol., 13, 249-259, 1987.

Karl, D., Letelier, R., Tupas, L., Dore, J., Christian, J., and Hebel, D.: The role of nitrogen fixation in biogeochemical cycling in the subtropical North Pacific Ocean, Nature, 388, 533-538, 1997.

Legendre, L., Demers, S., Yentsch, C. M., and Yentsch, C. S.: The ${ }^{14} \mathrm{C}$ method: Patterns of dark $\mathrm{CO}_{2}$ fixation and DCMU correction to replace the dark bottle 1, 2, Limnol. Oceanogr., 28, 9961003, 1983.

Li, W. and Dickie, P.: Light and dark ${ }^{14} \mathrm{C}$ uptake in dimly-lit oligotrophic waters: relation to bacterial activity, J. Plank. Res., 13, 29-44, 1991.

Li, W. K. W., Irwin, B. D., and Dickie, P. M.: Dark fixation of ${ }^{14}$ C: Variations related to biomass and productivity of phytoplankton and bacteria, Limnol. Oceanogr., 38, 483-494, 1993.

Lipschultz, F.: A time-series assessment of the nitrogen cycle at BATS, Deep-Sea Res. Pt. II, 48, 1897-1924, 2001.
Markager, S.: Dark uptake of inorganic ${ }^{14} \mathrm{C}$ in oligotrophic oceanic waters, J. Plank. Res., 20, 1813-1836, 1998.

Merbt, S. N., Stahl, D. A., Casamayor, E. O., Martí, E., Nicol, G. W., and Prosser, J. I.: Differential photoinhibition of bacterial and archaeal ammonia oxidation, FEMS Microbiol. Lett., 327, 4146, 2012.

Middelburg, J. J.: Chemoautotrophy in the ocean, Geophys. Res. Lett., 38, L24604, https://doi.org/10.1029/2011GL049725, 2011.

Moran, M. A.: Genomics and metagenomics of marine prokaryotes, Microbial Ecology of the Oceans, 2nd Edn., 91-129, 2008.

Nielsen, E. S.: The Use of Radio-active Carbon (C14) for Measuring Organic Production in the Sea, ICES J. Mar. Sci., 18, 117140, 1952.

Nielsen, E. S.: Dark fixation of $\mathrm{CO}_{2}$ and measurements of organic productivity, With remarks on chemo-synthesis, Physiol. Plantarum, 13, 348-357, 1960.

Palovaara, J., Akram, N., Baltar, F., Bunse, C., Forsberg, J., PedrósAlió, C., González, J. M., and Pinhassi, J.: Stimulation of growth by proteorhodopsin phototrophy involves regulation of central metabolic pathways in marine planktonic bacteria, P. Natl. Acad. Sci. USA, 111, E3650-E3658, 2014.

Petersen, G. H.: On the analysis of dark fixation in primary production computations, ICES J. Mar. Sci., 38, 326-330, 1979.

Prakash, A., Sheldon, R., and Sutcliffe Jr, W.: Geographic Variation of Oceanic ${ }^{14}$ C Dark Uptake, Limnol. Oceanogr., 1991, 30-39, 1991.

Reinthaler, T., Van Aken, H. M., and Herndl, G. J.: Major contribution of autotrophy to microbial carbon cycling in the deep North Atlantic, Äôs interior, Deep-Sea Res. Pt. II, 57, 15721580, 2010.

Segura-Noguera, M. M., Curless, S. E., Church, M. J., and Karl, D. M.: Ammonium distribution at Station ALOHA in the North Pacific Subtropical Gyre, ASLO Ocean Sciences Meeting, Honolulu, HI, February 2014.

Steinberg, D. K., Van Mooy, B. A., Buesseler, K., Boyd, P. W., Kobari, T., and Karl, D. M.: Bacterial vs. zooplankton control of sinking particle flux in the ocean's twilight zone, Limnol. Oceanogr., 53, 1327-1338, 2008.

Taguchi, S.: Dark fixation of $\mathrm{CO}_{2}$ in the subtropical north Pacific Ocean and the Weddell Sea, Bulletin of Plankton Society of Japan (Japan), 30, 115-124, 1983.

Wang, W.-L., Moore, J. K., Martiny, A. C., and Primeau, F. W.: Convergent estimates of marine nitrogen fixation, Nature, 566, 205-211, 2019.

Williams, P. J. 1. B., Quay, P. D., Westberry, T. K., and Behrenfeld, M. J.: The oligotrophic ocean is autotrophic, Annu. Rev. Mar. Sci., 5, 535-549, 2013.

Yool, A., Martin, A. P., Fernandez, C., and Clark, D. R.: The significance of nitrification for oceanic new production, Nature, 447 , 999-1002, 2007. 